\title{
Phytochemical content and antioxidant activity of selected wild ulam/vegetables consumed by indigenous Jakun community in Taman Negara Johor Endau Rompin (TNJER), Malaysia
}

\author{
Mohd Noor, H.S., *Abu Bakar, M.F., Abu Bakar, F.I., Ismail, N.A., Sanusi, S.B. and \\ Mohamed, M.
}

Centre of Research for Sustainable Uses of Natural Resources (CoR-SUNR), Faculty of Applied Sciences and Technology, Universiti Tun Hussein Onn Malaysia (UTHM), Hab Pendidikan Tinggi Pagoh, KM 1,

Jalan Panchor, 84600 Muar, Johor, Malaysia

\begin{abstract}
Article history:
Received: 4 May 2019

Received in revised form: 10

June 2019

Accepted: 12 June 2019

Available Online: 24 June

2019
\end{abstract}

Keywords:

Antioxidant,

Jakun community,

Phytochemical,

Taman Negara Johor Endau Rompin,

Ulam

\section{DOI:}

https://doi.org/10.26656/fr.2017.4(1).179

\begin{abstract}
This study aimed to investigate the phytochemical content and antioxidant activity of selected wild ulam/vegetables consumed by indigenous Jakun Community in Taman Negara Johor Endau Rompin (TNJER), Malaysia. Five ulam/vegetables were collected from TNJER, Malaysia namely Dillenia suffruticosa (pucuk simpuh), Amischotolype griffithii (tebu gogok), Paederia foetida (pucuk sekentut), Gnetum gnemon (pucuk empeng), and Barringtonia macrostachya (pucuk putat). Total phenolic content (using Folin-Ciocalteu) and total flavonoid content (using aluminium chloride colorimetric), as well as antioxidant activity using 2,2-diphenylpicrylhydrazyl (DPPH) and 2,2'-azino-bis(3 -ethylbenzothiazoline-6-sulphonic acid) (ABTS) assays were determined spectrophotometrically. For the phytochemical study, D. suffruticosa showed the highest value of total phenolic content $(93.87 \pm 0.10 \mu \mathrm{g}$ gallic acid equivalent $/ \mathrm{mL})$ while $B$. macrostachya displayed the highest value of total flavonoid content $(115.06 \pm 21.54 \mu \mathrm{g}$ rutin equivalent $/ \mathrm{mL}$ ) as compared to all samples tested. For the antioxidant activity, $G$. gnemon showed the lowest $\mathrm{EC}_{50}$ value in $\mathrm{DPPH}$ assay with the value of $3.92 \pm 1.52 \mu \mathrm{g}$ ascorbic acid $/ \mathrm{mL}$, indicated the strongest antioxidant potential. Meanwhile, $D$. suffruticosa showed the highest scavenging activity using ABTS assay $\left(\mathrm{EC}_{50}\right.$ value, 7.93 $\mu \mathrm{g} / \mathrm{mL}$ ). In conclusion, ulam/vegetables of TNJER are rich in phytochemicals and antioxidant which can be a great potential for use in complementary and alternative medicines as well as functional food applications.
\end{abstract}

\section{Introduction}

Being a tropical country, Malaysia is well-known for its richness in the biodiversity of many indigenous ulam/ vegetables which grow naturally in the wild (Aralas et al., 2009). In Malaysia, the consumption of raw ulam/ vegetable is considered as a common traditional healthy diet by many people due to their health-promoting properties (Chan et al., 2014). Majority of Malay restaurants in this country also serve ulam as a side dish to be eaten with rice (staple food) and sometimes, ulam may also be blanched, sautéed, curried or fried (Husain et al., 2004; Chan et al., 2014). Historically, ulam is used for many years in folk medicines either to prevent or cure the diseases which make them to receive great attention in spite of their flavourful popular side dishes (Reihani and Azhar, 2014). Currently, over 120 species of traditional vegetables from various plant families in Malaysia have been identified and regarded as ulam
(Aralas et al., 2009). Recent research has identified a vast variety of antioxidant from wild ulam/vegetables throughout the world especially Malaysia (Reihani and Azhar, 2014). Phytochemical (from plants) elements in the diet play a major role in contributing to human health (Nahak et al., 2014). Consumption of ulam/vegetables are good for health as they lower the risk of getting diseases such as cancer, diabetes, cardiovascular diseases, Alzheimer's disease and atherosclerosis due to presence of various forms of phytochemicals and antioxidants; polyphenol compounds including flavonoids and total phenolic compounds (Abdul Karim et al., 2014; Ahmad et al., 2014). In general, vegetables are considered to be among the top four common daily diets by Malaysians as they offer various health benefits to humans (Norimah et al., 2008). To date, there is still little information on the phytochemical content and antioxidant activity of Malaysian wild ulam/vegetables 
consumed by indigenous local community. Hence, this study aimed to investigate the phytochemical content and antioxidant activity of $80 \%$ methanolic extracts from selected wild ulam/vegetables consumed by Jakun Community in Taman Negara Johor Endau Rompin (TNJER).

\section{Materials and methods}

\subsection{Sample preparation}

The selected ulam/vegetables were Dillenia suffruticosa (family name: Dilleniaceae; local name: pucuk simpuh), Amischotolype griffithii (family name: Commelinaceae; local name: tebu gogok), Paederia foetida (family name: Rubiaceae; local name: pucuk sekentut), Gnetum gnemon (family name: Gnetaceae; local name: pucuk empeng), and Barringtonia macrostachya (family name: Lecythidaceae; local name: pucuk putat). The fresh samples were collected from the Jakun Community in TNJER, Malaysia which was then cleaned and stored at $-80^{\circ} \mathrm{C}$ overnight, followed by lyophilised for $48 \mathrm{hrs}$. Then, the dried vegetables were ground into powder and stored at $-20^{\circ} \mathrm{C}$ in darkness for further analysis.

\subsection{Sample extraction}

Sample of $0.1 \mathrm{~g}$ was mixed with $25 \mathrm{~mL}$ of $80 \%$ methanol. The mixture was agitated on an orbital shaker set at $200 \mathrm{rpm}$ for $2 \mathrm{hrs}$ followed by filtration by using Whatman filter paper and the supernatant was stored at $20^{\circ} \mathrm{C}$ in a freezer. The samples were extracted for phytochemical and antioxidant activity analysis. Each test was done in triplicate to ensure the accuracy of the results.

\subsection{Determination of phytochemical content}

\subsubsection{Total phenolic content}

Total phenolic content was determined using FolinCiocalteu reagent done by Velioglu et al. (1998) with some modifications. The absorbance values were obtained spectrophotometrically at $750 \mathrm{~nm}$ against zero absorbance (T60 Aurora Oasis Scientific, Inc., China). Gallic acid was used as a standard and the results were expressed as $\mu \mathrm{g}$ gallic acid equivalents $/ \mathrm{ml}$ ( $\mu \mathrm{g}$ GAE/ $\mathrm{mL})$.

\subsubsection{Total flavonoid content}

Total flavonoid was measured using aluminium chloride colorimetric method (Zhishen et al., 1999). The absorbance was measured spectrophotometrically at 510 $\mathrm{nm}$ against zero absorbance (T60 Aurora Oasis Scientific, Inc., China). Rutin was used as a standard and results were expressed as $\mu \mathrm{g}$ rutin equivalent/ml ( $\mu \mathrm{g} \mathrm{RE} /$ $\mathrm{mL})$.

\subsection{Determination of antioxidant activity}

2.4.1 DPPH (2, 2-diphenyl-2-pycrylhydrazyl) free radical scavenging action

Free radical model, 2, 2-diphenyl-2-pycrylhydrazyl (DPPH) was used to determine the antioxidant activity (Mensor et al., 2001). The absorbance was measured spectrophotometrically at $518 \mathrm{~nm}$ against blank (T60 Aurora Oasis Scientific, Inc., China). The radical scavenging activity was calculated as below:

Antioxidant activity $(\%)=100$ - (Absorbance sampleabsorbance blank/absorbance control) x 100

The scavenging percentage of all samples was plotted, and the final result was expressed as an $\mathrm{EC}_{50}$ value $(\mu \mathrm{g} / \mathrm{mL})$.

\subsubsection{ABTS (2,2'-azinobis (3-ethylbenzthiazoline)-6- sulphonic acid) radical scavenging assay}

ABTS free radical decolorization assay was carried out according to Re et al. (1999) with slight modification. The absorbance values were measured spectrophotometrically at $734 \mathrm{~nm}$ (T60Aurora Oasis Scientific, Inc., China) and the radical scavenging was expressed as $\mu \mathrm{g}$ ascorbic acid equivalent antioxidant capacity $/ \mathrm{mL}(\mu \mathrm{g}$ AEAC/mL).

\subsection{Statistical analysis}

Statistical analysis was done using Analysis of Variance (ANOVA) and the results were expressed as mean \pm standard deviation. In ANOVA, the differences between the mean values were considered significantly different when the value of $p<0.05$ was obtained.

\section{Results}

\subsection{Total phenolic content (TPC)}

The results showed that the total phenolic content of ulam/vegetables ranged from $17.08 \pm 1.02$ to $93.87 \pm 0.10$ $\mu \mathrm{g}$ gallic acid equivalent $/ \mathrm{mL}$. Pucuk simpuh had the highest total phenolic content with the value of $93.87 \pm 0.10 \mu \mathrm{g}$ gallic acid equivalent $/ \mathrm{mL}$, followed by pucuk empeng, pucuk putat, pucuk sekentut and tebu gogok with the values of $89.58 \pm 3.76,65.89 \pm 0.82$, $37.02 \pm 0.10$ and $17.08 \pm 1.02 \mu \mathrm{g}$ gallic acid equivalent/ $\mathrm{mL}$, respectively (Table 1$)(\mathrm{p}<0.05)$.

\subsection{Total flavonoid content (TFC)}

The results for the total flavonoid content of wild ulam/vegetables in this study ranged from $24.90 \pm 5.30$ to $115.06 \pm 21.54 \mu \mathrm{g}$ rutin equivalent $/ \mathrm{mL}$. Pucuk putat showed the highest total flavonoid content with the value of $115.06 \pm 21.54 \mu \mathrm{g}$ rutin equivalent $/ \mathrm{mL}$, followed by pucuk empeng, pucuk simpuh, pucuk sekentut and tebu 
Table 1. Phytochemical and antioxidant activity of ulam/vegetables

\begin{tabular}{lcccc}
\hline Sample & TPC $(\mu \mathrm{g} / \mathrm{mL})$ & TFC $(\mu \mathrm{g} / \mathrm{mL})$ & DPPH $\left(\mu \mathrm{g} / \mathrm{mL}^{2} \mathrm{EC}_{50}\right.$ & ABTS $(\mu \mathrm{g} / \mathrm{mL})$ \\
\hline Pucuk simpuh & $93.87 \pm 0.10^{\mathrm{a}}$ & $55.38 \pm 5.85^{\mathrm{c}}$ & $5.482 \pm 0.32^{\mathrm{d}}$ & $7.93 \pm 0.02^{\mathrm{a}}$ \\
Pucuk putat & $65.89 \pm 0.82^{\mathrm{c}}$ & $115.06 \pm 21.54^{\mathrm{a}}$ & $10.67 \pm 0.26^{\mathrm{c}}$ & $7.71 \pm 0.03^{\mathrm{a}}$ \\
Pucuk empeng & $89.58 \pm 3.76^{\mathrm{b}}$ & $94.11 \pm 13.21^{\mathrm{b}}$ & $3.92 \pm 1.52^{\mathrm{e}}$ & $7.80 \pm 0.01^{\mathrm{a}}$ \\
Tebu gogok & $17.08 \pm 1.02^{\mathrm{e}}$ & $24.90 \pm 5.30^{\mathrm{e}}$ & $48.68 \pm 1.47^{\mathrm{a}}$ & $7.35 \pm 0.03^{\mathrm{a}}$ \\
Pucuk sekentut & $37.02 \pm 0.10^{\mathrm{d}}$ & $50.78 \pm 9.6^{\mathrm{d}}$ & $40.66 \pm 0.06^{\mathrm{b}}$ & $4.51 \pm 0.03^{\mathrm{b}}$ \\
\hline
\end{tabular}

Values are presented in mean \pm standard deviation $(n=3)$. Different alphabet superscript in the same row are significantly different $(\mathrm{p}<0.05)$.

gogok with the value of $94.11 \pm 13.21,55.38 \pm 5.85$, $50.78 \pm 9.62$ and $24.90 \pm 5.30 \mu \mathrm{g}$ rutin equivalent $/ \mathrm{mL}$, respectively (Table 1) $(\mathrm{p}<0.05)$.

\subsection{DPPH (2, 2 -diphenyl-2-picrylhydrazyl) free radical scavenging action}

The $\mathrm{EC}_{50}$ value (equivalent concentration to give $50 \%$ effect) was determined to better quantify the radical scavenging activity in the samples, the lower $\mathrm{EC}_{50}$ value indicated the stronger DPPH radical scavenging activity. Pucuk empeng showed the lowest $\mathrm{EC}_{50}$ value with $3.92 \pm 1.52 \mu \mathrm{g} / \mathrm{mL}$, indicated the stronger DPPH radical scavenging activity while tebu gogok showed the highest $\mathrm{EC}_{50}$ value with $48.6 \pm 1.47 \mu \mathrm{g} / \mathrm{mL}$. $\mathrm{EC}_{50}$ values for pucuk sekentut, pucuk putat and pucuk simpuh were $40.66 \pm 0.06 \mu \mathrm{g} / \mathrm{mL}, 10.67 \pm 0.26 \mu \mathrm{g} / \mathrm{mL}$ and $5.482 \pm 0.32$ $\mu \mathrm{g} / \mathrm{mL}$, respectively. The results showed that they were statistically significant difference between all samples for scavenging free-radical activity $(\mathrm{p}<0.05)$ (Table 1).

\subsection{ABTS radical scavenging}

The results showed that pucuk simpuh had the highest value with $7.93 \pm 0.02 \mu \mathrm{g}$ ascorbic acid $/ \mathrm{mL}$ followed by pucuk empeng, pucuk putat, tebu gogok and pucuk sekentut with the values of $7.80 \pm 0.01,7.71 \pm 0.03$, $7.35 \pm 0.03$, and $4.51 \pm 0.03 \mu \mathrm{g}$ ascorbic acid $/ \mathrm{mL}$, respectively (Table 1).

\section{Discussion}

The health-promoting effect of vegetables, fruits, whole grains, and nuts may be contributed by polyphenols and antioxidant constituents (Pandey and Rizvi, 2009). For instance, phenolic compounds are secondary metabolites commonly found in plants such as vegetables, fruits and spices (Chua et al., 2014). They are natural antioxidants and play a role as scavengers of free radicals and hence, they form an essential part of the human diet as they may contribute directly to antioxidative action in the body (Duh et al., 1999; Shahidi and Ambigaipalan, 2015). It is believed that their radical scavenging ability is due to their hydroxyl groups (Hatano et al., 1989). The level of total phenolic contents in wild ulam/vegetables varied from $17.08 \pm 1.02$ to $93.87 \pm 0.10 \mu \mathrm{g}$ gallic acid equivalent $/ \mathrm{mL}$. Dillenia suffruticosa (pucuk simpuh) demonstrated the highest phenolic content with the value of $93.87 \pm 0.10 \mu \mathrm{g}$ gallic acid equivalent $/ \mathrm{mL}$. Previous study demonstrated that Cosmos caudatus (ulam raja) had the highest amount of total phenols as compared to other vegetables such as Polyscias pinnata, Pluchea indica, Nothopanax scutellarius, Talinum triangulare, Pilea melastomoides and Etlingera elatior (Andarwulan et al., 2010).

Flavonoids are the most diverse group of natural compounds which possess a broad spectrum of chemical and biological properties (Prasad et al., 2010). Not only for the antioxidant activity, but they also have the properties as anti-carcinogenic and anti-arteriosclerosis (Wong et al., 2006). In this study, the total flavonoid content of wild ulam/vegetables varied from $24.90 \pm 5.30$ to $115.06 \pm 21.54 \mu \mathrm{g}$ rutin equivalent $/ \mathrm{mL}$. The previous study reported that the flavonoid content of the vegetables ranged from 0.3 to $143 \mathrm{mg} / 100 \mathrm{~g}$ fresh weight, with the highest value was found in Sauropus androgynus (L) Merr or known as cekur manis in Malay. This might be due to the presence of quercetin and kaempferol (Andarwulan et al., 2010). Other factors such as climate and cultivar were also identified as the main factors affecting the structure of phenolics and other bioactive compounds (Bolling et al., 2010).

Antioxidant inhibits the cellular damage by its known mechanism, free radical scavenging. DPPH free radical scavenging is one of the methods used to evaluate antioxidant activities with a very limited period of time compared to other methods. The $\mathrm{EC}_{50}$ value was determined to better quantify and determine the radical scavenging activity in the samples. Gnetum gnemon or pucuk empeng showed the lowest $\mathrm{EC}_{50}$ value with $3.92 \pm 1.52 \mu \mathrm{g} / \mathrm{mL}$ as shown in Table 1. Therefore, it possessed the strongest DPPH radical scavenging activity. There was also significant difference for all samples for $80 \%$ methanolic extract $(\mathrm{p}<0.05)$. The previous study also reported that the stick of $G$. gnemon extracted with methanol gave the highest scavenging activity with a value of $38.679 \pm 0.745 \%$ (Wazir et al., 2011). Other study demonstrated that $C$. caudatus (ulam raja) extract inhibited linoleic acid oxidation which resulted in greatest DPPH free radical scavenging activity (Andarwulan et al., 2010). Many studies showed 
that the extract with a high amount of polyphenol content was able to exhibit high antioxidant activity (Bolling et al., 2010; Reihani and Azhar, 2012). In this study, the extract of pucuk empeng corresponded with this suggestion but not in pucuk simpuh since it showed a relatively low antioxidant activity but higher total phenolic content. Poor specificity of the total phenolic content assay might be the reason for this disagreement (Singleton et al., 1999; Escarpa and González, 2001). Besides, the number of phenolic compounds present may affect its respond towards Folin-Ciocalteu reagent (Singleton et al., 1999).

ABTS radical scavenging assay is a method used to study the antioxidant potential and the results varied from that of DPPH radical scavenging activity method. In this assay, the highest scavenging activity was found in pucuk simpuh with the value of $7.93 \pm 0.02 \mu \mathrm{g}$ ascorbic $\mathrm{acid} / \mathrm{mL}$. However, the results from ABTS assay showed that pucuk simpuh had the highest scavenging activity and it was varied from DPPH method whereby pucuk empeng had the highest scavenging activity. The difference in the trend of the results might be due to the different mechanism of action in both methods.

Phytochemicals such as the phenolic and flavonoid compounds contributed to the antioxidant activity in the wild ulam/vegetables extracts when correlation analysis was performed. Some correlations were observed between antioxidant activity and phytochemical content for several samples. From this analysis, DPPH free radical scavenging activity of pucuk putat was highest, moderately positively correlated with the phenolic content of the extracts $(r=0.615)$ while tebu gogok showed the lowest positive correlation with total phenolic content $(r=0.264)$. The results were in agreement with the previous studies which showed a strong correlation between the total phenolic content and antioxidant activity (Deighton et al., 2000; Martínez et al., 2012).

Meanwhile, total flavonoid content of pucuk putat showed the strongest positive correlation with antioxidant activity in all samples tested $(r=0.999)$, which was in agreement with an earlier study which also reported that antioxidant activity was closely related to the phenolic and flavonoid content (Sabli et al., 2012; Ling et al., 2015). Furthermore, ABTS radical scavenging of the extracts of pucuk putat was positively correlated to the total phenolic $(r=0.982)$ and pucuk empeng showed the lowest correlation with total phenolic content $(r=0.480)$. However, total flavonoid content of the pucuk simpuh extract was highly correlated with ABTS free radical scavenging $(r=$ 0.987), while pucuk putat showed lowest correlation with ABTS free radical scavenging $(r=0.718)$.

\section{Conclusion}

Wild ulam/vegetables in Taman Negara Johor Endau Rompin (TNJER) are rich in phytochemicals and antioxidant which can be a great potential for use in complementary and alternative medicines as well as functional food applications.

\section{Conflict of Interest}

The authors do not have any conflicts of interest regarding the content of the present work.

\section{Acknowledgments}

This study was funded by Ministry of Higher education of Malaysia (MoHE) under Fundamental Research Grant Scheme (Vot: K099). We also thank the Jakun Community for their assistance during the sample collection in Taman Negara Johor Endau Rompin (TNJER), and Universiti Tun Hussein Onn Malaysia (UTHM) for research grant support (H277) as well as the laboratory facilities.

\section{References}

Abdul Karim, F., Suleiman, M., Rahmat, A. and Abu Bakar, M.F. (2014). Phytochemicals, antioxidant and antiproliferative properties of five moss species from Sabah, Malaysia. International Journal of Pharmacy and Pharmaceutical Sciences, 6(10), 292-297.

Ahmad, S., Sukari, M.A., Ismail, N., Ismail, N.S., Abdul, A.B., Abu Bakar, M.F., Kifli, N. and Ee, G.C.L. (2015). Phytochemicals from Mangifera pajang Kosterm and their biological activities. $B M C$ Complementary and Alternative Medicine, 15(1), 83. https://doi.org/10.1186/s12906-015-0594-7

Andarwulan, N., Batari, R., Sandrasari, D.A., Bolling, B. and Wijaya, H. (2010). Flavonoid content and antioxidant activity of vegetables from Indonesia. Food Chemistry, 121(4), 1231-1235. https:// doi.org/10.1016/j.foodchem.2010.01.033

Aralas, S., Mohamed, M. and Fadzelly Abu Bakar, M. (2009). Antioxidant properties of selected salak (Salacca zalacca) varieties in Sabah, Malaysia. Nutrition and Food Science, 39(3), 243250. https://doi.org/10.1108/00346650910957492

Bolling, B.W., Dolnikowski, G., Blumberg, J.B. and Chen, C.Y. (2010). Polyphenol content and antioxidant activity of California almonds depend on cultivar and harvest year. Food Chemistry, 122(3), 819-825. https://doi.org/10.1016/ j.foodchem.2010.03.068 
Chan, E.W.C., Tan, Y.P., Chin, S.J., Gan, L.Y., Kang, K.X., Fong, C.H., Chang, H.Q. and How, Y.C. (2014). Antioxidant properties of selected fresh and processed herbs and vegetables. Free Radicals and Antioxidants, 4(1), 39-46. https:// doi.org/10.5530/fra.2014.1.7

Chua, H.P., Nicholas, D. and Suzalyna, M. (2014). Phenolic and flavonoid contents and antioxidant activities of selected dabai (Canarium odontophyllum) genotypes. Journal of Tropical Agriculture and Food Science, 42, 105-114.

Deighton, N., Brennan, R., Finn, C. and Davies, H.V. (2000). Antioxidant properties of domesticated and wild rubus species. Journal of the Science of Food and Agriculture, 80(9), 1307-1313. https:// doi.org/10.1002/1097-0010(200007)80:9<1307::AID -JSFA638>3.0.CO;2-P

Duh, P.D., Tu, Y.Y. and Yen, G.C. (1999). Antioxidant activity of water extract of Harng Jyur (Chrysanthemum morifolium Ramat). LWT - Food Science and Technology, 32(5), 269-277. https:// doi.org/10.1006/fstl.1999.0548

Escarpa, A. and González, M.C. (2001). Approach to the content of total extractable phenolic compounds from different food samples by comparison of chromatographic and spectrophotometric methods. Analytica Chimica Acta, 427(1), 119-127. https:// doi.org/10.1016/S0003-2670(00)01188-0

Hatano, T., Edamatsu, R., Hiramatsu, M., Mori, A., Fujita, Y. and Yasuhara, D. (1989). Effects of interaction of tannins with co-existing substances. VI. Effects of tannins and related polyphenols on superoxide anion radical and on DPPH radical. Chemical and Pharmaceutical Bulletin, 37(8), 20162021. https://doi.org/10.1248/cpb.37.2016

Husain, K., Zabidi, M. S., Jantan, I., Jamal, J.A. and Jalil, J. (2004). Etnobotani ke atas tumbuhan yang digunakan sebagai ulam di Malaysia. Jurnal Sains Kesihatan Malaysia, 2(1), 5-8.

Ling, A.L.M., Yasir, S., Matanju, P. and Abu Bakar, M.F. (2015). Effect of different drying techniques on the phytochemical content and antioxidant activity of Kappaphycus alvarezii. Journal of Applied Phycology, 27(4), 1717-1723. https:// doi.org/10.1007/s10811-014-0467-3

Martínez, R., Torres, P., Meneses, M.A., Figueroa, J.G., Pérez-Álvarez, J.A. and Viuda-Martos, M. (2012). Chemical, technological and in vitro antioxidant properties of cocoa (Theobroma cacao L.) coproducts. Food Research International, 49(1), 39-45. https://doi.org/10.1016/j.foodres.2012.08.005

Mensor, L.L., Menezes, F.S., Leitão, G.G., Reis, A.S.,
Santos, T.C., Coube, C.S. and Leitão, S.G. (2001). Screening of Brazilian plant extracts for antioxidant activity by the use of DPPH free radical method. Phytotherapy Research, 15(2), 27-30. https:// doi.org/10.1002/ptr.687

Nahak, G., Suar, M. and Sahu, R.K. (2014). Antioxidant potential and nutritional values of vegetables: a review. Research Journal of Medicinal Plants, 8(2), 50-81. https://doi.org/10.3923/rjmp.2014.50.81

Norimah, A.K., Safiah, M., Jamal, K., Haslinda, S., Zuhaida, H., Rohida, S., Fatimah, S., Norazlin, S., Poh, B.K., Kandiah, M., Zalilah, M.S., Wan Manan, W.M., Fatimah, S. and Azmi, M.Y. (2008). Food consumption patterns: Findings from the Malaysian Adult Nutrition Survey (MANS). Malaysian Journal of Nutrition, 14(1), 25-39.

Pandey, K.B. and Rizvi, S.I. (2009). Plant polyphenols as dietary antioxidants in human health and disease. Oxidative Medicine and Cellular Longevity, 2(5), 270-278. https://doi.org/10.4161/oxim.2.5.9498

Prasad, K.N., Chew, L.Y., Khoo, H.E., Kong, K.W., Azlan, A. and Ismail, A. (2010). Antioxidant capacities of peel, pulp, and seed fractions of Canarium Odontophyllum Miq. Fruit. Journal of Biomedicine and Biotechnology, 2010, 1-8. https:// doi.org/10.1155/2010/871379

Re, R., Pellegrini, N., Proteggente, A., Pannala, A., Yang, M. and Rice-Evans, C. (1999). Antioxidant activity applying an improved ABTS radical cation decolorization assay. Free Radical Biology and Medicine, 26(9), 1231-1237. https://doi.org/10.1016/ S0891-5849(98)00315-3

Reihani, S.F.S. and Azhar, M.E. (2012). Antioxidant activity and total phenolic content in aqueous extracts of selected traditional Malay salads (Ulam). International Food Research Journal, 19(4), 14391444.

Sabli, F., Mohamed, M., Rahmat, A., Ibrahim, H. and Abu Bakar, M.F. (2012). Antioxidant properties of selected Etlingera and Zingiber species (Zingiberaceae) from Borneo Island. International Journal of Biochemistry, 6(1), 1-9. https:// doi.org/10.3923/ijbc.2012.1.9

Shahidi, F. and Ambigaipalan, P. (2015). Phenolics and polyphenolics in foods, beverages and spices: Antioxidant activity and health effects-A review. Journal of Functional Foods, 18(Part B), 820-897. https://doi.org/10.1016/j.jff.2015.06.018

Singleton, V.L., Orthofer, R. and Lamuela-Raventos, R.M. (1999). Analysis of total phenols and other oxidation substrates and antioxidants by means of Folin-Ciocalteu reagent. Methods in Enzymology, 
299, 152-178. https://doi.org/10.1016/S0076-6879

(99)99017-1

Velioglu, Y.S., Mazza, G., Gao, L. and Oomah, B.D. (1998). Antioxidant activity and total phenolics in selected fruits, vegetables, and grain products. Journal of Agricultural and Food Chemistry, 46(10), 4113-4117. https://doi.org/10.1021/jf9801973

Wazir, D., Ahmad, S., Muse, R., Mahmood, M. and Shukor, M.Y. (2011). Antioxidant activities of different parts of Gnetum gnemon L. Journal of Plant Biochemistry and Biotechnology, 20(2), 234. https://doi.org/10.1007/s13562-011-0051-8

Wong, S.P., Leong, L.P. and Koh, J.H. (2006). Antioxidant activities of aqueous extracts of selected plants. Food Chemistry, 99(4) 775-783. https:// doi.org/10.1016/j.foodchem.2005.07.058

Zhishen, J., Mengcheng, T. and Jianming, W. (1999). The determination of flavonoid contents in mulberry and their scavenging effects on superoxide radicals. Food Chemistry, 64(4), 555-559. https:// doi.org/10.1016/S0308-8146(98)00102-2 